\title{
Smallholders' Chicken Management System: The Case of Jimma Horro District of Kelem Wollega Zone Western Oromia, Ethiopia
}

\author{
Soresa Shuma \\ Department of Animal Science, College of Agriculture Veterinary Medicine, Dambi Dollo University, Amhara, Ethiopia
}

Email address:

soriyeshuma@gmail.com

\section{To cite this article:}

Soresa Shuma. Smallholders' Chicken Management System: The Case of Jimma Horro District of Kelem Wollega Zone Western Oromia, Ethiopia. American Journal of Management Science and Engineering. Vol. 6, No. 4, 2021, pp. 77-86. doi: 10.11648/j.ajmse.20210604.11

Received: May 20, 2021; Accepted: July 9, 2021; Published: July 16, 2021

\begin{abstract}
This study was piloted in Jimma Horro District of Kellem Wollega Zone, through the objective of evaluating smallholders' chicken managing system of the area. An organized questionnaire and Participatory Rural Appraisal (PRA) approaches significant to Small holder chicken management were used to collect data. A study stayed piloted on the designated Households relating Small Holder Chicken Controlling Structure. The most leading chicken running classification in the survey part was a survival extensive method which is constructed on native and better chickens with hunting besides periodic additional breast-feeding of home-based particles then home nutrition rejections. As the views of respondent's home chicken is basis of revenue that profits females subsequently around 99.4\% poultry coverage of the District are described to be kept through females who remain supposed to be accountable for creation nearly entirely the main directions regarding chicken. About $86.7 \%$ of the respondents have no separate chicken household. Serious limitations of the smallholder chicken manufacture in the revision area were moderately due to the dominant lowly supervision observes, in specific disease, predator, absence of appropriate vigor attention, and lowly accommodation. It was decided that exertions have to be finished to move the manufacture standard to semi intensive aiming on business concerned with invention founded on searching with a universal care of facilities such as well-being, covering, delay, credit and selling to make it fruitful and supportable.
\end{abstract}

Keywords: Searching, Chicken Management System, Households

\section{Introduction}

\subsection{Background of the Study}

Different studies show that similarly to other African countries, village level poultry production contributes to various livelihood outcomes in Ethiopia, including gender equality, income generating, as well as its role in cultural, religious and traditional practices $[14,1,4]$. In Ethiopia poultry are widespread and almost every rural family owns chicken [15]. The chicken population in Ethiopian is estimated to be about 56.87 million [2]. About $97.82 \%$ of the poultry production in Ethiopia is traditionally managed [4]. In the rural areas of Ethiopia, most of the farmers have no separate house for their chickens and the chickens live together with the human population within one house. In line to this, the farmers have no planned feeding of their chickens and scavenging is almost the only source of feed and they have no planned breeding $[12,7]$.

Local chicken takes the higher percent in the country $(95.86 \%)$ as well as in the study area of north western Tigray $(95.6 \%)$ in terms of population [2]. However, the output (egg and meat) is low, have small body size, low hatchability at about $70 \%$, high mortality estimated at about $40-60 \%$ of chicks die during their first eight weeks of age mainly due to disease and predators as compared to exotic chicken [11].

To improve the poultry production, several exotic chicken breeds have been disseminated to the farmers over the last 50 years in the country [11] and in the study areas the chicken was distributed for the last 15 years [17]. But the adoption of these exotic chicken breed in most parts of the country is not promising due to its hindrance by a set of factors including sub-optimal management, lack of supplementary feed, low genetic potential and high mortality rate due to diseases and 
predators $[14,16]$. In the study area there is no any documented study focusing to the chicken management and the perception of farmers on exotic chicken breed. Hence, the objective of this study was to assess chicken management condition and to assess the perception of farmers on the benefits and constraints of producing exotic chicken breed in the study Woredas.

\subsection{Statement of the Problem}

Indigenous and exotic chicken production is they ecotypes intended the pastoral growers at what time observed in expressions of its searching for utmost of its dietary wants [9]. In accumulation, revisions have recognized numerous obstacles obstructing chicken husbandry which contain killers, nourishing and selling [3]. To this end, the restrictions disturbing chicken fabrication in Kelem Wollega and in specific Jimma Horro District make sure not be present considered. Thus, the investigation was supported obtainable to decide the effect of administration on the equal of native in addition exotic chicken manufacture in Jimma Horro District of Kellem Wollega zone of Ethiopia.

\subsection{Objective(s)}

\subsubsection{General Objective}

To assess small holders' chicken management system in Jimma Horro district.

\subsubsection{Specific Objectives}

1) To study housing and feeding system of chicken under small holder farmers in Jimma Horro District.

2) To identify major disease of poultry manufacturer in ranchers running situations in Jimma Horro District.

\subsection{Research Question}

How is chicken management under small- holder farmers in Jimma Horo district?

\subsection{Importance of the Study}

As studies identified main disease of native and exotic chicken creation and also generate some base line information for future studies.

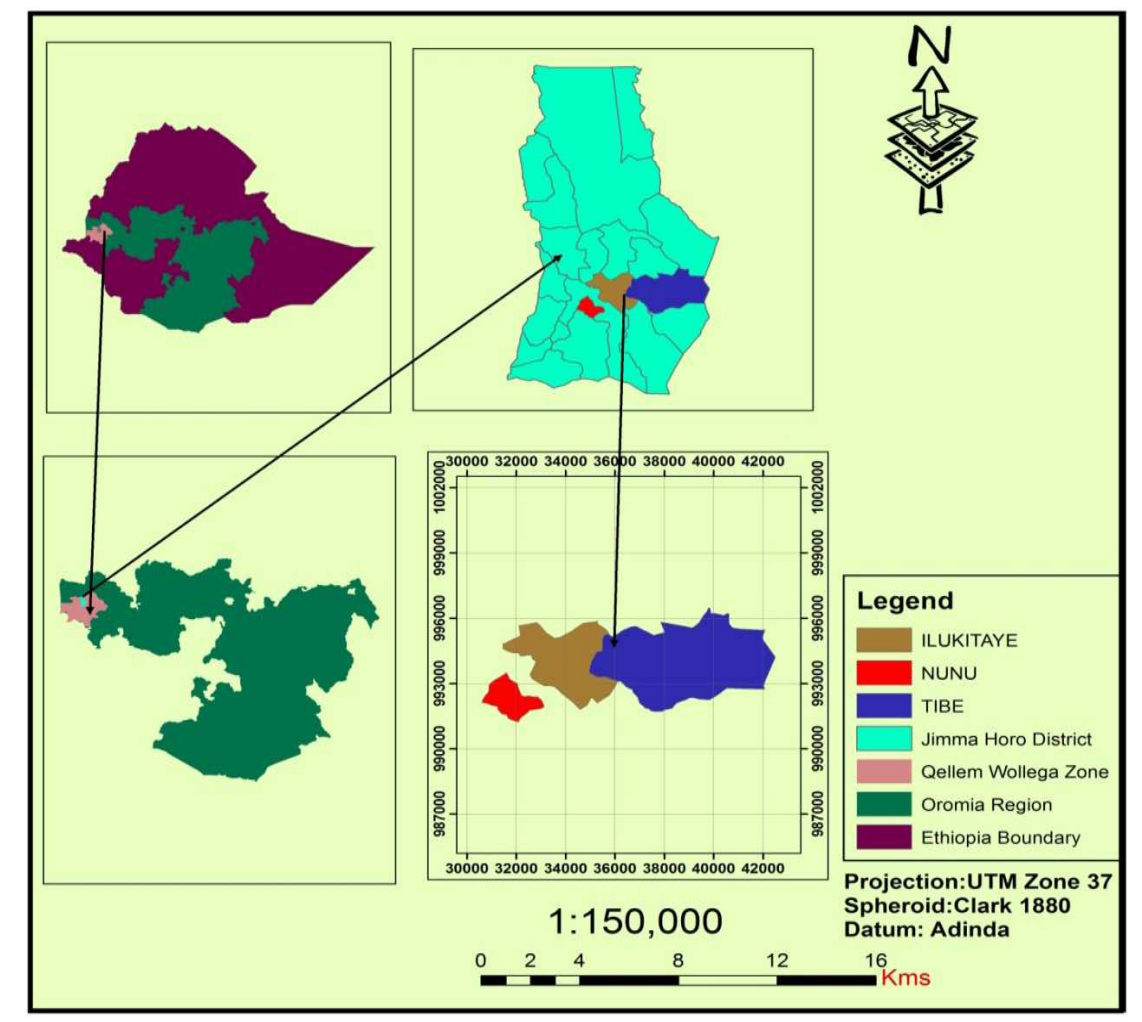

Figure 1. Map of Jimma Horro Horo District (Study areas).

\section{Materials and Methods}

\subsection{Description of Study Areas}

The study was conducted in Nunu, Tibe and Ilu kitaye Kebeles of Jima Horro District of Kellem Wollega Zone. Jimma Horro district is located at $641 \mathrm{~km}$ West of Addis Ababa. The altitude of the district ranges between 1400 and
1800 meters above sea level, with average annual minimum and maximum temperature of $18^{\circ} \mathrm{C}$, and $27^{\circ} \mathrm{C}$, respectively while the annual rainfall ranges from 700 to $1000 \mathrm{~mm}$ (Ethiopian Digital Elevation Model, 2018). In the study area livestock and crop farming is the major economic activity of the district. The livestock resource of the study district comprises of 66267 cattle, 19421 sheep, 13647 goats, 257 horses, 6809 mules, 9873 donkeys, and 68401 chickens [5]. The total human population of the district is about 56403, of 
which $50 \%$ is reported to be male (Ethiopian Digital Elevation Model 2018).

\subsection{Selection of the Study Areas and Method of Data Collection}

\subsubsection{Selection of the Study Areas}

The three Kebeles Nunu (lowland), Ilu kitaye (mid altitude) and Tibe (highland) were purposively selected based on the representativeness, accessibility and availability of exotic and indigenous chicken ecotypes.

\subsubsection{Households Sampling Techniques}

A rapid informal field survey and discussion with the District livestock and fishery office experts were made to know accessibility and availability of exotic and indigenous chicken ecotypes in study areas. After further discussion with the district agricultural development agents and key informants, a total of 9 kebeles ( 3 from Tibe, 3 from Ilu Kitaye and 3 from Nunu) were selected and discussion was conducted with them.

After all the chicken owners of the selected Kebeles were listed during the reconnaissance study then the total numbers of the households to be interviewed were estimated according to Yamane [18] with 92\% confidence level. After knowing the total number of farmer's selection was done randomly.

$$
\mathrm{n}=\mathrm{N} / 1+\mathrm{N}(\mathrm{e})^{2} .
$$

Where; $\mathrm{n}=$ sample size

$\mathrm{N}=$ total number of households

$1=$ probability the event occurring

$\mathrm{e}=$ maximum variability or margin of error $=8(0.08)$

\subsubsection{Data Collection}

\section{Primary Data Source}

Data was generated by administrating a structured questionnaire, employing field measurements, organizing group discussion and from secondary sources. Basically the study was composed of Chicken Management System.

The questionnaire was translated in to Afaan Oromo. It was pre-tested before administration and some rearrangement and correction was made in accordance with respondents' perception. Information's gathered through questionnaires were: socio economic characteristics of the respondents like sex, age, education level, household size, livestock possession, socio economic benefit of chicken production and major production of egg and meat, constraints; reproductive performances like age at first egg, purpose of keeping chicken, feed and feeding situations, like major feed sources, supplementation, water source; major diseases of chicken in the areas.

Information was collected from individual farmers, extension officers, key informants and village group using both indigenous and exotic production. The exercises was aimed at assessing the perspectives of the chicken management system including intra household dynamics (division of labor, access to and control over of resources and decision making on resources), Information on indigenous and exotic breeds of chicken including; flock characteristics and ownership, and flock performance, use pattern, off take and loss of chicken and all aspects of chicken managements were collected.

Secondary sources: secondary data were collected from district livestock and fishery resource office and the respective kebele offices of livestock and fishery resource to complement the distribution, number of chicken across the different kebeles and management system.

Finally, closer visits in and around the residential quarters of the villages were made in order to obtain first hand observation on different aspects of chicken management from individual households and to involve women in the households since their participation in the village meetings and other data collection activities is expected to be rather restricted.

\subsection{Statistical Analysis}

The result of collected data were analyzed using analysis of variance (ANOVA) following the General Linear Model Procedure of the Statistical Analysis System [10] at $\alpha=0.05$. Mean separation was done for results with significant variations.

Data collected through questionnaire, observation, and interviews were analyzed by descriptive statistics using Statistical Package for Social Sciences [13] version 20.

\section{Results and Discussion}

\subsection{Characteristics of Respondents}

Household characteristics of respondents in study areas were illustrated in (Table 1) below. Of the interviewed households, about $72.1 \%$ and $27.9 \%$ were male and females respectively. About $93.3 \%$ were married and the remaining $2.4 \%, 2.4 \%$ and $1.8 \%$ were single, divorced and widowed, respectively. Education plays great role in transferring technology to farmers and to initiate their willingness to adopt technologies. Higher percentages of respondents in the study areas were educated (elementary to high school and college) and While only $23.6 \%$ were illiterate. The presence of educated farmers in the study district could be an opportunity in management of chicken and other livestock production.

In relations of their employment, popular of the defendants $(91.5 \%)$ were ranchers. The popular of the surveyed families drop in age under 60 percent years old, showing that the creative work essential for upkeep, running of chicken was main in the household. The mean household scope were $6.16 \pm 0.2,5.76 \pm 0.3$ and $5.87 \pm 0.2$ for Tibe, Ilu Kitaye and Nunu kebeles, respectively whereas the overall family sizes per house hold of the study areas was $5.9 \pm 0.2$ ranging from $1-11$ persons.

About $75 \%$ of the defendants remained Protestant while the left over $14.5 \%$ and $10.3 \%$ are Orthodox and Muslim, individually. Nearby $83.6 \%$ and $16.4 \%$ of the defendants described to have practice of 2 to 14 and 15 to 40 years in chicken rising, individually. 
Table 1. Demographic appearances of respondents in the study areas.

\begin{tabular}{|c|c|c|c|c|}
\hline \multirow{3}{*}{ Variable } & \multicolumn{4}{|l|}{ Kebeles } \\
\hline & Tibe & Ilu Kitaye & Nunu & over all \\
\hline & $(\mathrm{N}=55) \%$ & $(\mathrm{~N}=55) \%$ & $(\mathrm{~N}=55) \%$ & $(\mathrm{~N}=165) \%$ \\
\hline \multicolumn{5}{|l|}{ Sex of respondent } \\
\hline Male & 67.3 & 75.5 & 74.5 & 72.1 \\
\hline Female & 32.7 & 24.5 & 25.4 & 27.9 \\
\hline \multicolumn{5}{|l|}{ Marital status } \\
\hline Single & 0 & 1.8 & 5.5 & 2.4 \\
\hline Married & 100 & 96.4 & 83.6 & 93.3 \\
\hline Divorced & 0 & 1.8 & 5.5 & 2.4 \\
\hline Widowed & 0 & 0 & 5.5 & 1.83 \\
\hline \multicolumn{5}{|l|}{ Educational level } \\
\hline Illiterate & 18.2 & 25.5 & 27.3 & 23.6 \\
\hline Read and write & 45.5 & 31 & 23.6 & 33.3 \\
\hline Grade 5-8 & 20 & 30.9 & 14.5 & 21.8 \\
\hline Grade $9-12$ & 12.7 & 12.7 & 21.8 & 15.8 \\
\hline College and above & 3.6 & 0 & 12.7 & 5.5 \\
\hline \multicolumn{5}{|l|}{ Major occupation } \\
\hline Farmers & 90.1 & 96.4 & 89.1 & 91.53 \\
\hline Traders & 5.5 & 2.5 & 0 & 2.66 \\
\hline Depend on mining activity & 0.8 & 1.1 & 0 & 0.63 \\
\hline Fisher men & 0 & 0 & 0 & 0 \\
\hline Government worker & 3.6 & 0 & 11.9 & 5.16 \\
\hline \multicolumn{5}{|l|}{ Age of households } \\
\hline$>60$ years & 7.00 & 7.00 & 8 & 7 \\
\hline Between 35 and 60 years & 63.70 & 58.80 & 59.64 & 60.71 \\
\hline Between 19 and 34 years & 29 & 34.00 & 32.00 & 32 \\
\hline Average family size/household (Mean \pm SE) & $6.16 \pm 0.266$ & $5.76 \pm 0.308$ & $5.87 \pm 0.229$ & $5.93 \pm 0.167$ \\
\hline Age of Respondents & $45 \pm 0.984$ & $43.13 \pm 0.778$ & $42.64 \pm 0.676$ & $43.59 \pm 0.479$ \\
\hline
\end{tabular}

$\mathrm{N}=$ Number of defendants, $\%=$ Percent, $\mathrm{SE}=$ standard error.

\subsection{House hold and Livestock Holdings}

\subsubsection{Land-living Scope and Land Practice}

Lad size and land practice of defendants in survey areas were described in (Table 2). The mean plot holding of the study kebeles was $2 \pm 0.2,1.9 \pm 0.1$ and $0.8 \pm 0.1$ for Tibe, Ilu kitaye and Nunu kebeles respectively with the overall mean 1.53.

Table 2. Average plot field (ha) and land practice of the respondents in the survey areas.

\begin{tabular}{|c|c|c|c|c|}
\hline \multirow{3}{*}{ Variable } & \multicolumn{4}{|l|}{ Kebeles } \\
\hline & Tibe $(\mathrm{N}=55)$ & Ilu Kitaye ( $(=55)$ & Nunu $(\mathrm{N}=55)$ & Over all $(\mathrm{N}=165)$ \\
\hline & Mean \pm SE & Mean \pm SE & Mean \pm SE & $\operatorname{Mean} \pm$ SE \\
\hline Total land & $2 \pm 0.20$ & $1.9 \pm 0.10$ & $0.8 \pm 0.10$ & $1.53 \pm 0.10$ \\
\hline Annual crop & $1.01 \pm 0.10$ & $1.04 \pm 0.10$ & $0.41 \pm 0.04$ & $0.82 \pm 0.10$ \\
\hline Perennial crop & $0.61 \pm 0.10$ & $0.5 \pm 0.004$ & $0.27 \pm 0.03$ & $0.46 \pm 0.03$ \\
\hline Grazing & $0.34 \pm 0.10$ & $0.3 \pm 0.30$ & $0.19 \pm 0.10$ & $0.27 \pm 0.03$ \\
\hline Fallow & $0.04 \pm 0.20$ & $0.08 \pm 0.20$ & $0.01 \pm 0.10$ & $0.04 \pm 0.10$ \\
\hline
\end{tabular}

$\mathrm{N}=$ Number of respondents, $\%=$ Percent

The highest average land holding of $(2 \pm 0.2)$ ha was recorded in Tibe (highland) kebele while the smallest average land holding $(0.8 \pm 0.1 \mathrm{ha})$ was recorded in Nunu (lowland) kebele. The overall mean plot field per family of the survey wereda was (1.53 ha).

\subsubsection{Livestock Holding and Composition}

The livestock holding and livestock structure is depicted on (Table 3) below.

Regarding the livestock holding, local breed are the dominant in the experimented families of survey district.
Table 3. Livestock stock and arrangement of in study areas.

\begin{tabular}{|c|c|c|c|c|}
\hline \multirow{3}{*}{ Variable } & \multicolumn{4}{|l|}{ Kebeles } \\
\hline & Tibe (55) & Ilu Kitaye (55) & Nunu (55) & Over all $(\mathrm{N}=165)$ \\
\hline & Mean \pm SE & Mean \pm SE & Mean \pm SE & $\operatorname{Mean} \pm$ SE \\
\hline Cow & $2.8 \pm 0.2$ & $2.6 \pm 0.3$ & $1.25 \pm 0.2$ & $2.2 \pm 0.1$ \\
\hline Oxen & $1.8 \pm 0.2$ & $2 \pm 0.3$ & $0.78 \pm 0.1$ & $1.53 \pm 0.1$ \\
\hline Calf & $1.98 \pm 0.2$ & $1.8 \pm 0.2$ & $0.73 \pm 0.1$ & $1.5 \pm 0.1$ \\
\hline Heifers & $1.85 \pm 0.9$ & $1.96 \pm 0.3$ & $0.67 \pm 0.1$ & $1.5 \pm 0.1$ \\
\hline Bull & $1.53 \pm 0.2$ & $1.73 \pm 0.2$ & $0.64 \pm 0.2$ & $1.3 \pm 0.1$ \\
\hline Sheep & $3.07 \pm 0.3$ & $2.35 \pm 0.3$ & $0.62 \pm 0.2$ & $2 \pm 0.2$ \\
\hline Goat & $0.15 \pm 0.1$ & $0.4 \pm 0.1$ & $0.6 \pm 0.1$ & $0.4 \pm 0.1$ \\
\hline Donkey & $0.73 \pm 0.1$ & $0.58 \pm 0.1$ & $0.31 \pm 0.1$ & $0.54 \pm 0.1$ \\
\hline Chicken & $15.78 \pm 1.9$ & $13.75 \pm 1.5$ & $6.6 \pm 0.7$ & $12.04 \pm 0.1$ \\
\hline
\end{tabular}


The average number of chicken was found to be higher $(15.778 \pm 1.9)$ in highland kebele compared to the lowland $(6.6 \pm 0.7)$ kebele of the study areas. This result was advanced than the middling herd scope of 9.2 chickens/ household described by Mekonnen [6] for Dale Wereda in Ethiopia.

\subsection{Chicken Herd Organization and Features}

\subsubsection{Herd Organization}

Flock structure is designated in positions of the numeral and percentage of the unlike age collections and sexual category in a group. The total numbers of chicken available in the study area was 1986 of which 868, 755 and 363 were in Tibe, Ilu Kitaye and Nunu kebeles, respectively.

The largest flock size of the study kebeles were $15.78 \pm 1.9$ (Ranging from 3-105) in Tibe (highland) kebele as well as $13.75 \pm 1.45$ (ranging from 2-60) in Ilu kitaye (Mid altitude) and the smallest flock size was $6.6 \pm 0.65$ (ranging 2-20) in Nunu (low land) kebele. The general middling group scope per households stayed 12.04 chickens which ranged from $2-105$.

Table 4. Herd scope and ratio of the defendant keeping dissimilar scope of poultry in study areas.

\begin{tabular}{|c|c|c|c|c|c|c|c|}
\hline \multirow{2}{*}{ Kebele } & Cock & Hen & Pullate & Cockerels & Chicks & \multirow{2}{*}{ Over all } & \multirow{2}{*}{ Range } \\
\hline & Mean \pm SE & $\operatorname{Mean} \pm \mathrm{SE}$ & Mean \pm SE & Mean \pm SE & $\operatorname{Mean} \pm \mathrm{SE}$ & & \\
\hline Tibe & $2.9 \pm 0.58$ & $4.05 \pm 0.7$ & $3.29 \pm 0.8$ & $2.95 \pm 0.9$ & $4.35 \pm 0.5$ & $15.78 \pm 1.8$ & $3-105$ \\
\hline Ilu Kitaye & $2.04 \pm 0.1$ & $3.40 \pm 0.3$ & $2.33 \pm 0.3$ & $1.75 \pm 0.2$ & $2.69 \pm 0.3$ & $13.75 \pm 1.4$ & $2-60$ \\
\hline Nunu & $0.93 \pm 0.4$ & $3.16 \pm 0.2$ & $0.49 \pm 0.1$ & $0.38 \pm 0.1$ & $1.38 \pm 0.4$ & $6.6 \pm 0.7$ & $2-20$ \\
\hline Grand mean & $1.96 \pm 0.3$ & $3.54 \pm 0.3$ & $2.04 \pm 0.3$ & $1.69 \pm 0.3$ & $2.81 \pm 0.2$ & $12.04 \pm 0.9$ & $2-105$ \\
\hline
\end{tabular}

There were a high proportion of hens which accounted for $29.4 \%$ (Figure 2).

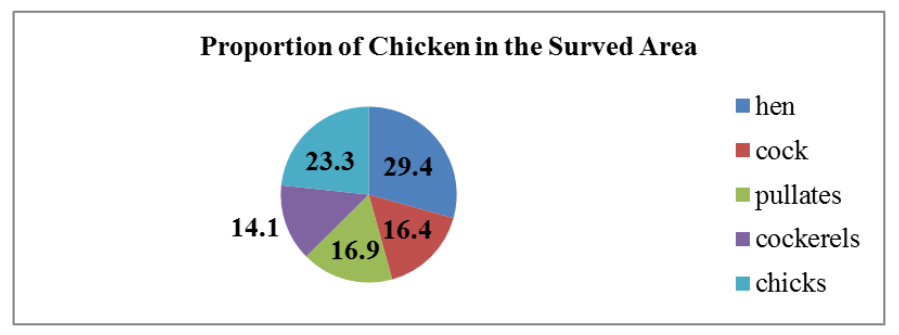

Figure 2. Proportions of chickens in the surveyed households.

Table 5. Plumage color of local chicken of the study areas.

\begin{tabular}{|c|c|c|c|c|}
\hline \multirow{2}{*}{ Variables } & \multicolumn{4}{|l|}{ Kebeles } \\
\hline & Tibe $(\mathrm{N}=55) \%$ & Ilu kitaye $(\mathrm{N}=55) \%$ & Nunu $(\mathrm{N}=55) \%$ & Over all $(N=165) \%$ \\
\hline Black & 30 & 33 & 33 & 32 \\
\hline Red & 32.8 & 34 & 32 & 33 \\
\hline Blue & 4 & 7.3 & 8 & 6 \\
\hline White & 15 & 10 & 12 & 13 \\
\hline Brown & 8.5 & 7.9 & 9 & 8 \\
\hline Grew & 9.7 & 7.8 & 6 & 8 \\
\hline
\end{tabular}

$\mathrm{N}=$ Number of respondents, $\%=$ Percent

\subsubsection{Flock Characteristics}

Color of local chicken in study areas is depicted and summarized in (Table 5). The feathers standards of the indigenous poultry establish in the survey parts were varied (dark, white, red, grey, blue, brown,). Red (33\%) plumage was the dominant color followed by black (32) in local ecotype chicken of the study area.

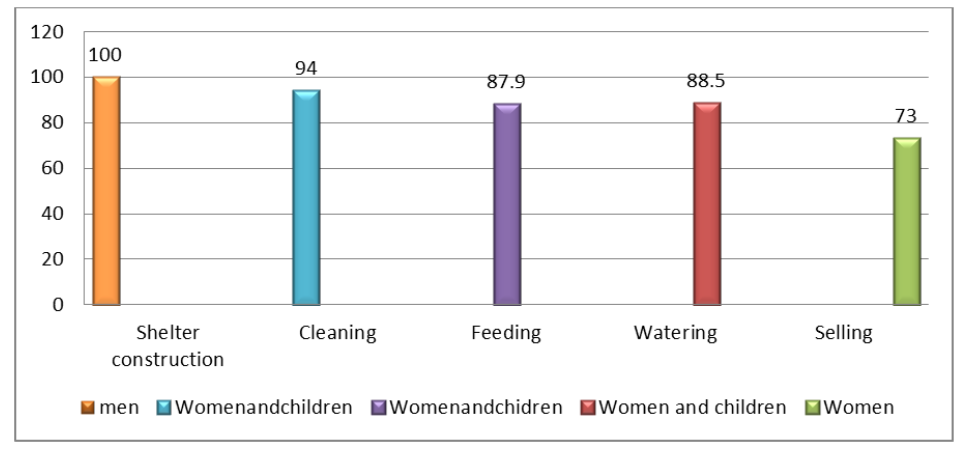

Figure 3. Intra household decision-making power among different family members. 


\subsection{Small Holder Chicken Management System in the District}

\subsubsection{Feedstuff and Serving Applies}

As accessible in (Table 6), mainstream (94.5\%) of defendants described that the poultry feeding system is scavenging with small additional supplementation of cereals and food refusals of the households. The survey result indicated that type of grain supplement in study area was both sorghum and barley (95.8\%). About 95.8\% respondents supplement farm produced feed. Majority $(98.2 \%)$ of respondents don't use feeding trough or equipment's they simply feed their chicken by spread on ground. In feeding chicken about $99.4 \%$ of the homes afford additional feedstuffs for unlike stage clusters organized only about $0.6 \%$ offer feed according the age group.

Table 6. Feeding practices and feeding system of chicken in study areas.

\begin{tabular}{|c|c|c|c|c|}
\hline \multirow{2}{*}{ Variable } & \multicolumn{4}{|l|}{ Kebeles } \\
\hline & Tibe $(\mathrm{N}=55) \%$ & Ilu Kitaye $(\mathrm{N}=55) \%$ & Nunu $(\mathrm{N}=55) \%$ & Over all $(\mathrm{N}=165) \%$ \\
\hline \multicolumn{5}{|l|}{ Feeding System } \\
\hline Scavenging only & 0 & 0 & 16.4 & 5.5 \\
\hline Scavenging with additional supplementation & 100 & 100 & 83.6 & 94.5 \\
\hline \multicolumn{5}{|l|}{ Regularity of nourishing } \\
\hline One time in day & 1.8 & 21.8 & 12.7 & 12.1 \\
\hline Two times in day & 22.6 & 78.7 & 87.3 & 62.9 \\
\hline Trice times a day & 75 & 0 & 0 & 25 \\
\hline \multicolumn{5}{|l|}{ Category of particle addition } \\
\hline Sorghum & 0 & 0 & 12.7 & 4.2 \\
\hline Both sorghum and barley & 100 & 100 & 87.3 & 95.8 \\
\hline \multicolumn{5}{|l|}{ Basis of nutrition addition } \\
\hline Homestead made & 100 & 100 & 87.3 & 95.8 \\
\hline Bought & 0 & 0 & 12.7 & 4.2 \\
\hline \multicolumn{5}{|l|}{ Method of addition } \\
\hline Giving on lad & 94.5 & 100 & 100 & 98.2 \\
\hline By Federer & 5.5 & 0 & 0 & 1.8 \\
\hline \multicolumn{5}{|l|}{ Form of supplementation } \\
\hline Separate different class & 1.8 & 0 & 0 & 0.6 \\
\hline Together the whole group & 98.2 & 100 & 100 & 99.4 \\
\hline \multicolumn{5}{|l|}{ Time of feeding } \\
\hline Afternoon only & 0 & 9.1 & 40 & 16.4 \\
\hline Morning and afternoon & 94.5 & 90.9 & 21.8 & 69.1 \\
\hline Morning, afternoon and evening & 5.5 & 0 & 38.2 & 14.6 \\
\hline
\end{tabular}

$\mathrm{N}=$ Number of respondents, $\%=$ Percent

Table 7. Evening housing, resources used for building households and regularity of washing the household in the appraised houses.

\begin{tabular}{lllll}
\hline Variable & Kebeles & & & \\
\cline { 2 - 5 } & Tibe (N=55) \% & Ilu Kitaye (N=55) \% & Nunu (55)\% & Over all (N=165)\% \\
\hline Night Shelter & 16.4 & 60 & 49.1 & 41.8 \\
Kitchen & 9.1 & 10.9 & 7.3 & 9.1 \\
Main house & 36.4 & 27.3 & 43.6 & 35.8 \\
Perch & 38.2 & 1.8 & 0 & 13.3 \\
Purposive constructed house & & & & 0 \\
Materials used for chicken house construction & 0 & 0 & 0 & 30.9 \\
Mad block and thatch & 90.9 & 1.8 & 0 & 3 \\
Timber and straw & 9.1 & 0 & 0 & 6.1 \\
Timber and wavy strong & 18.2 & 0 & 0 & 6.7 \\
Rate of washing chicken household & 20 & 0 & 0 & 13.9 \\
All time & 41.8 & 0 & 0 & 73.3 \\
Each two times & 20 & 100 & 100 & \\
Each 3-6 time & & & \\
On one occasion a week & & & \\
\hline
\end{tabular}

$\mathrm{N}=$ Number of respondents, $\%=$ Percent

\subsubsection{Shelter Providing System of Chicken}

Providing shelter is essential to chicken as it protects them against predators, theft, rough weather (rain, sun, cold and wind) and to provide shelter for egg laying and broody hen.
However, the survey revealed that about $86.7 \%$ of the respondents do not have separate chicken house for their chicken. Only $13.3 \%$ of respondents construct chicken house purposely (Table 7). This might be attributed to lack of experience and enough bud-gets of the respondents to 
construct separate chicken houses. Between the defendants who raised chicken household distinctly around $30.9 \%$ of them construct chicken household from timber and straw. Concerning rate of washing the households, around $73.3 \%$, $13.9 \%, 6.7 \%, 6.1 \%$ of respondents clean their houses once a week, 3-6 days, every two days, every day, and respectively.

\subsubsection{Provision of Water}

$\mathrm{H}_{2} \mathrm{O}$ acting significant portion in the ingestion and digestion of the birds in adding to helping help as a means to manage certain significant injections. Even though differences in foundations of $\mathrm{H}_{2} \mathrm{O}$ and regularity of spraying, exactly completely of the defendants delivered water for their chickens (Table 8). Nearly completely of the defendants $(99 \%)$ afford water for their chicken in the district. Concerning the basis of water, $98 \%$ of the defendants practice stream water for their chicken. Around $44.8 \%$ of the defendants clean intake resources on one occasion a week.

Table 8. Running of $\mathrm{H}_{2} \mathrm{O}$ in appraised defendants of the study parts

\begin{tabular}{|c|c|c|c|c|}
\hline \multirow{2}{*}{ Variables } & \multicolumn{4}{|l|}{ Kebeles } \\
\hline & Tibe $(\mathrm{N}=55) \%$ & Ilu Kitaye $(\mathrm{N}=55) \%$ & Nunu $(\mathrm{N}=55) \%$ & Over All $(\mathrm{N}=165) \%$ \\
\hline \multicolumn{5}{|l|}{ Provision of water } \\
\hline Yes & 100 & 98.2 & 98.2 & 99 \\
\hline No & 0 & 1.2 & 1.8 & 1 \\
\hline \multicolumn{5}{|l|}{ Source of water } \\
\hline Bore hole & 0 & 2.4 & 3.6 & 2 \\
\hline River water & 100 & 97.6 & 96.4 & 98 \\
\hline Wood & 47.3 & 1.8 & 3.6 & 17.6 \\
\hline Plastic & 57.2 & 84.8 & 94.5 & 78.8 \\
\hline Stone & 0 & 9.1 & 1.8 & 3.6 \\
\hline \multicolumn{5}{|c|}{ Frequency of cleaning drinker } \\
\hline One a day & 1.8 & 5.5 & 7.3 & 4.8 \\
\hline Every three days & 20 & 10.9 & 78.2 & 36.4 \\
\hline Once a week & 78.2 & 43.6 & 12.7 & 44.8 \\
\hline
\end{tabular}

$\mathrm{N}=$ Number of respondents, $\%=$ Percent

\subsubsection{Health Management}

Health care practices of the defendants in the assessed parts are depicted below in figure 5. In the study areas majority of the defendants $(63.4 \%)$ vaccinates their chickens. About $54 \%$ of respondents replied that the highest disease of the assessed parts Newcastle and 36\% reported to be coccidiosis. Most of the respondents (79\%) treat their chicken in consultation with veterinarian while only $10 \%$ prepared not receipts any degree when their chicken develops sick.

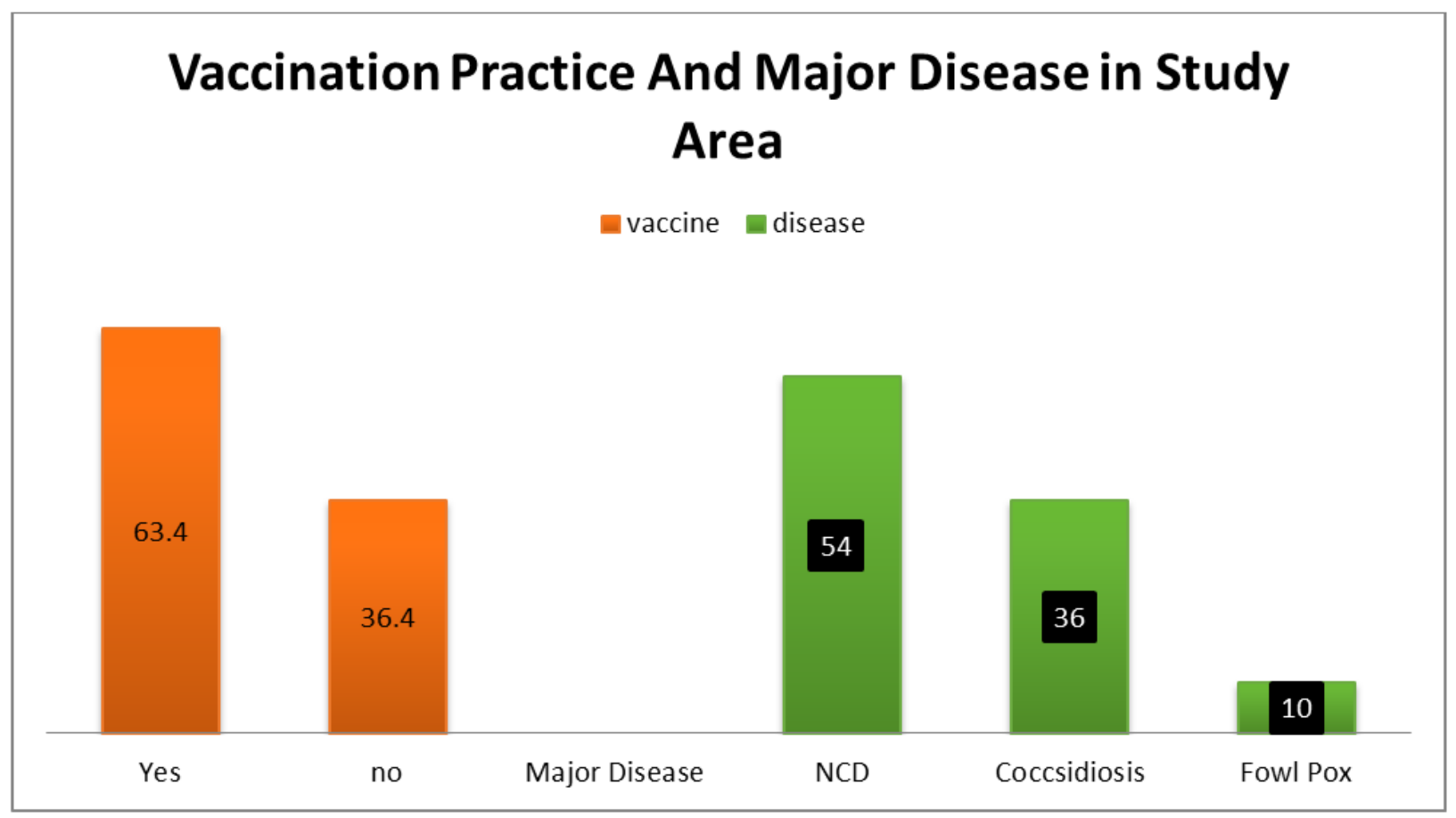

Figure 4. Vaccination practice and major diseases in study area. 


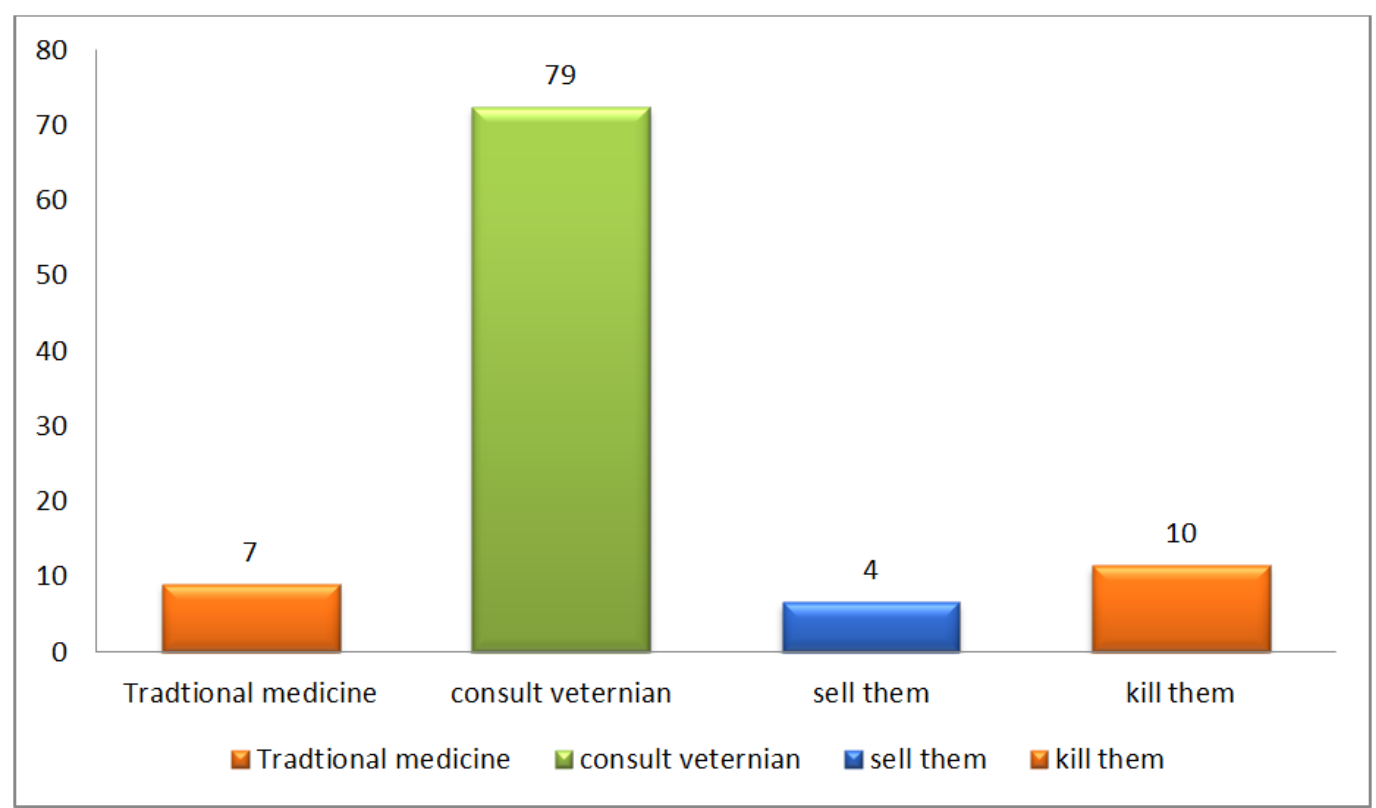

Figure 5. Measurement taken when chicken gets sick.

\subsubsection{Broody Hen Management}

The total Mother Nature of the broody fowl managing of the plotted part is illustrated in Table 9. Ordinary development is the greatest usually practiced system for substituting and growing the proportions of groups. A bird frequently needs a shady and moderately home in the household for putting seeds. Later the seed were harvested; planters correct pot place for broody birds. Regularly they practice bamboo finished bags and they agree the fowl to take a seat simply on the surface land. Agriculturalists are identical aware and worried in the planning of suitable shell packets for development of moody fowl. Chicken produces usually concede brooding with upright feedstuff resources and suitable environment for developing poultry. Around $92.1 \%$ of the defendants practiced to hatch and brood their bird through the hot periods. Nearby $7.9 \%$ of the defendants ensure not require several exact optimal of period for development. A fowl has to brood after leaving eggs so that it would hatch, hatch the eggs and advance their early chickens. Yet, as contrasting to marketable level homesteads which choice in contradiction of pensiveness, growers (93.1\%) in the survey area area ended choice near broodiness grounded on unlike principles counting preceding presentation of the bird $(22.6 \%)$, form scope $(66.2 \%)$ and plenty feathers (11.3\%). Likewise, assed by [8] presented that $66.7 \%$ of the defendant's usage great form scope as a choice condition.

Table 9. Broody hen management in study areas.

\begin{tabular}{|c|c|c|c|c|}
\hline \multirow{2}{*}{ Parameter } & \multicolumn{4}{|l|}{ Kebeles } \\
\hline & Tibe $(\mathrm{N}=55) \%$ & Ilu Kitaye $(\mathrm{N}=55) \%$ & Nunu $(\mathrm{N}=55) \%$ & over all $(\mathrm{N}=165) \%$ \\
\hline \multicolumn{5}{|l|}{ Criteria for broody hen selection } \\
\hline Pervious performance & 21.4 & 22.2 & 24 & 22.5 \\
\hline Large body size & 67.79 & 70.5 & 60.5 & 66.2 \\
\hline Ample plumage & 10.9 & 7.3 & 15.5 & 11.3 \\
\hline \multicolumn{5}{|l|}{ Position of egg while incubating } \\
\hline Do not mind position & 100 & 100 & 100 & 100 \\
\hline Laid in the house & 100 & 100 & 100 & 100 \\
\hline \multicolumn{5}{|l|}{ Period of egg development } \\
\hline Hot period & 92.7 & 90.9 & 92.7 & 92.1 \\
\hline Rainy period & 3.6 & 3.6 & 3.6 & 3.6 \\
\hline Whichever period & 3.6 & 5.5 & 3.6 & 4.2 \\
\hline \multicolumn{5}{|l|}{ Shell containers for thoughtful fowl } \\
\hline Earthen container & 61.8 & 41.8 & 21.8 & 41.8 \\
\hline Bamboo made brooder & - & - & 3.6 & 1.2 \\
\hline On the ground & 1.8 & 27.3 & - & 9.7 \\
\hline \multicolumn{5}{|l|}{ Management of brooding fowl at period of development } \\
\hline Feedstuff and $\mathrm{H}_{2} \mathrm{O}$ close to brooding shell and protect challenge & 100 & 94.5 & 74.5 & 89.7 \\
\hline No special management other than usual & - & 5.5 & 25.5 & 10.3 \\
\hline
\end{tabular}

$\mathrm{N}=$ Number of respondents, $\%=$ Percent 
Table 10. The major reasons for culling of chickens in the Assed parts.

\begin{tabular}{|c|c|c|c|c|}
\hline \multirow{2}{*}{ Factor for removing of fowls } & \multicolumn{4}{|l|}{ Kebeles } \\
\hline & Tibe $(\mathrm{N}=55) \%$ & Ilu Kitaye $(\mathrm{N}=55) \%$ & Nunu $(\mathrm{N}=55) \%$ & over all $(\mathrm{N}=165) \%$ \\
\hline Sickness & 43.6 & 58.2 & 47.3 & 49.7 \\
\hline Lack of broodiness & 36.4 & 23.6 & 23.6 & 27.9 \\
\hline Old age & 12.7 & 7.3 & 29.1 & 16.4 \\
\hline Poor productivity & 7.3 & 10.9 & - & 6 \\
\hline
\end{tabular}

$\mathrm{N}=$ Number of respondents, $\%=$ Percent

\section{Summary, Conclusions and Recommendation}

\subsection{Summary}

The outcomes of the survey indicated that the average group proportions per home of the Jimma Horro District were 12.04 poultry the worth of which is greater than the countrywide middling. Poultry of the Locality are reserved below searching situation with addition. A massive figure of family females and families actively participate in chicken management by means of their individual indigenous and improved breed and native awareness of chicken controlling to create revenue and/or to accompaniment the protein necessity of the families. The greatest prevailing chicken management structures in the survey part were the extensive and semi intensive classifications built on the native and improved birds and searching with chance and periodic additional nourishing of home-based particles and home nutrition rejections with no exact chicken households.

The major chicken nourishing exercise in assessed district was searching with extra addition..

\subsection{Conclusion}

Newcastle disease followed by killer attack was the main limitations to chicken manufacture in the study area. Additional restraints involved absence of money and credit facility to increase their chicken manufacture, lowly controlling follows on nourishing, covering and infection switch, absence of practical evidence. Together, these factors resulted in decreased direct benefit of the farmers.

\subsection{Recommendations}

Consequently, the behind endorsements are advised built on the assessment outcome and the below real opinions.

1) Furthermore, running of systematic sickness preclusion instrument and suitable injection package will absolutely decrease death.

2) Shifting the yield of searching fowl in the assessed part by improving controlling methods that encourage expansion in output and diminish death.

3) Modest household building mainly planned for chicks by means of immediate accessible resources can easily save from injury.

4) A minute practical funding on growers' skill or information of additional nourishing and watering might advance efficiency of chickens.
5) There is a solid requirement to build up on the creativities of farmer's development in the part of facility of supportable recognition system and growers exercise package.

6) To expand the condition the Office of Livestock should fill the gaps with respect of inputs like Extension services and sets for improved operation of fowl expansion plan.

\section{References}

[1] Bush, Jennifer. (2006). The Threat of Avian Flu Predicted Impacts on Rural Livelihoods in CACC (Central Agricultural Census Commission), (2003): Statistical report on farm management Practices, livestock and farm managements Central Statistical Authority report of 2004- 2005, Vol. II, Addis Ababa, Ethiopia.

[2] CSA (central statistical Agency). (2015). Agricultural sample survey volume II report on livestock and Livestock characteristics Addis Ababa August 2015573 statical bulletin 573.

[3] Danda, M. K, Mwamachi., D. M, Lewal,. K and Jefa,. F. (2008), Characterization of the indigenous chicken sub-sector in the Coastal lowlands of Kenya. In: Proceedings of the 12th Kenya Agricultural Research Institute Biennial Scientific Conference, obi, Kenya, pp. 898-905.

[4] FAO (2010). Poultry meat and Eggs Agribusiness hand book. Director of Investment Centre Division.

[5] Kelem Wollega Zone Western Oromia, Ethiopia Jimma Horo Livestock office 2018).

[6] Mekonnen G., (2007). Characterization of smallholder poultry production and marketing system of Dale, wonsho and loka abaya weredas of southern Ethiopia. Msc. Thesis presented to the School of Graduate Studies of Hawassa University.

[7] Mengesha, M., Tamir, B. and Dessie, T. 2011. Village Chicken Constraints and Traditional Management Practices in Jamma District, South Wollo, Ethiopia. Livestock Research for Rural Development. 23 (37).

[8] Moges F, Tegegne A, Dessie T (2010). Local chicken production and marketing systems in Ethiopia: Characteristics and opportunities for market-oriented development. IPMS (Improving Productivity and Market Success) of Ethiopian Farmers Project Working Paper 24 Nairobi, Kenya, ILRI. 55.

[9] Nzioka M. (2000), Indigenous poultry production in the Katumani mandate area. In: Margo Kooijiman and E. Mukisira (Eds). Netherlands support to the National Agricultural Research Project Phase II. Proceedings of the end of project conference. 29th Nov.-1st Dec. 2002. KARI Headquarters, Nairobi, Kenya. 
[10] SAS (Statistical Analysis System), (2008). SAS Institute Inc., Cary, NC, USA. V. 9.25. Eskinder Aklilu, 2013. On-farm phenotypic characterization of indigenous chicken and chicken. school of graduate studies, Haramaya University, pp: 107.

[11] Solomon D. (2008a): Suitability of hay-box brooding technology to rural household poultry production system. Livestock, Research, Rural Development, 19 (1): Retrieved May 8, 2012, Solomon D., 2007b. Comparative nutritive value of Atella and industrial brewer's grains in chicken retrieved May 26, 2015.

[12] Solomon, D. (2007): Suitability of hay-box brooding technology to rural household poultry production System. Lives. Res. Rural Dev., 19: 71-74.

[13] SPSS (2011). Statistical Package for the Social Sciences (SPSS). Vision 20.0. IBM Corporation, SPSS Inc., Chicago IL.

[14] Tadelle Dessie, Million Tadesse, Alemu Yami and Peters, K. J.
2003 b. Village chicken production systems in Ethiopia: Use patterns and performance valuation and chicken products and socio-economic functions of chicken. Livestock Research for Rural Development, Vol. 15.

[15] Tadelle Dessie, Nigusie, D., Alemu Yami and Peters, K. J. 2003 a. The feed resource base and its potentials for increased poultry production in Ethiopia. World's Poultry Science Journal, 58, 77-87, Cambridge University Press.

[16] Tekelewold Hailemariam, Dadi, L., Yami, A. and Dana, N. 2006. Determinants of Adoption of Poultry Technology: A Double-Hurdle Approach. Livestock Research for Rural Development, Vol. 18 (3).

[17] Tselemti and Tahtay Koraro Office of Agriculture and Rural Development, 2016).

[18] Yamane T., (1967). Stastics: An introductory Analysis, $2^{\text {nd }}$ Ed., And And New York: Harper and Row. 